\title{
Basic Principles and Advancing the Popularization of Marxist Philosophy in Contemporary China
}

\author{
Dan Liu* \\ Shaanxi Vocational and Technical College, Xi'an 710199, Shaanxi Province, China \\ *Corresponding author: Dan Liu, 1005239297@qq.com
}

\begin{abstract}
With the current domestic reform and opening-up, China has increased the construction and development of social economy whereas Marx's philosophy has become a key research topic for social research scholars. This article focuses on the basic principles of the widespread practice of Marxism in the Chinese society and conducts a brief analysis on its journey of popularization.
\end{abstract}

Keywords: China; Marx's philosophy; Popularization

Publication date: June 2021; Online publication: June 30, 2021

\section{Introduction}

Different scholars have studied the widespread practice of Marxism from different angles and numerous research focused on advancing the popularization of Marxist philosophy. This current study on Marxist philosophy is based on the lives of the public in translating Marxist professional abstract theoretical knowledge into concrete images which is beneficial for public acceptance. Only in this way can it be accepted by the mass society.

\section{Overview of the popularization of Marxist philosophy}

The popularization of Marxist philosophy is a systematic study of the present situation of Marxism in China which allows for the translation of Marxist thought into a language that is easily understood by the public and subsequently, forming a fresh thought that would be accepted by the public. The Marxist thought have become a powerful weapon in transforming public values and the understanding of the world. In consideration of its nature and function, it has been decided that the Marxist philosophy should be popularized. In regard to the situation in China, it is important to study the popularization of Marxist philosophy. China has entered a rapid stage of social and economic development in which the spiritual views of the public require the guidance of Marxist philosophy as a theoretical basis to form action guidelines that are conducive to the social and economic development. This is the primary goal of the popularization of Marxist philosophy.

\section{Necessity of the popularization of Marxist philosophy}

With the domestic construction and development of the economy, the popularization of Marxist philosophy would face many challenges in its advancement. If philosophies are only abstract concepts, the actual value of those philosophies would not be revealed, hence the public would not understand the ideas behind those philosophies. The popularization and application of philosophies would be interfered by multiple factors in which for Marx's philosophy, people's values are important factors. It can be appreciated that the 
popularization of philosophy has become a profound connotation of philosophical thoughts that can be deeply understood by the general public.

\section{Popularization of Marxist philosophy}

\subsection{Marxist as a philosophical theory}

Marxist philosophy is a summary of the future development in terms of laws of thinking, nature, as well as the society in forming several classical theories. In the popularization of Marxist philosophy, the emphasis should be on the basic theory, however the classical theory of Marxism is more profound and abstract. In studies of the popularization of Marxist ideological and philosophical knowledge, these classical theories should be discussed in detailed. Being able to abstract them into ordinary knowledge may also promote the propaganda of Marx's philosophy.

\subsection{Achievement of propagandizing philosophical theories}

In promoting Marxist philosophy, it is necessary to focus on combining the development theory of socialism with Chinese characteristics in philosophical research. Research scholars have been actively exploring the innovation and integration of China's national situation with Marx's thought not only to contribute updated research results but also to promote the innovation and popularization of new philosophical theories. In the propaganda of Marx's thought, the popularization should be made understandable.

\subsection{Combination of the popularization of Marxist philosophy and social development}

The popularization of contemporary Marxist philosophy is to be orderly integrated into the domestic scientific concept of development. In the current context of China's national condition, the application of Marxist philosophy methodology and perspectives is to solve China's political, economic, and cultural development.

\section{Ways to advance the popularization of Marxist philosophy}

\subsection{Using "popular" language to elaborate abstract theories}

In promoting social popularization of Marxist philosophy in China, it is necessary to analyze and visualize its abstract theories by using the language of the mass society. Publication of Marxist philosophy books in "popular" language to explain the theories while being supplemented by a large number of cases enable the public to easily understand them and accept the philosophy as it would not require too much time to learn. Several scientific theories should also be converted into ordinary written information for elaboration to help the public understand them. However, during this period, it is not wise to fashion theoretical philosophies as more elaborated forms in order to eliminate the tendency of vulgarization. If the language used in books is too vulgar, it will affect the image of Marx's philosophy among the public.

\subsection{Applying the philosophy to guide life}

In the popularization of Marxist philosophy, other than its purpose to promote social stability, it also aims for the organic integration of philosophy and public life so that the Marxist philosophy can become a part of life. The use of Marx's thought in guiding practical work would realize the innovation and breakthrough of the theory. In regard to that, only through the organic integration of Marxist philosophy into daily life activities would bring it closer to the reality of society and eventually truly realizing the role of Marxist philosophy in guiding life. 


\subsection{Various publicity methods}

In view of promoting the popularization of Marxism, various publicity methods should be used. The most common means of information dissemination by the public should be used to promote the popularization and promotion of the widespread culture of Marxist philosophy. During publicity, the public's situation should be taken into account such as their way of life, customs, and understanding. Through the publication of several simple reading materials with contents of esoteric theories that have been translated into "popular" languages, these theories would then be understood by the public that have basic education.

\subsection{Serving the mass society as the essence}

Marxist philosophy is the integration of science and humanism which is applied to the domestic politics and economic situation in addition to the transformation of lives. The mass society should be focus in the application of Marxist philosophy. Its theory as the key which links Marxist philosophy to people's lives and the actual weapon of public transformation should serve the public. The party emphasizes people as its foundation and the purpose of its development is to serve the people wholeheartedly. Realizing the protection of social public rights and interests is the starting as well as the end point of the current party's work. Xiaoping Deng adheres to the three aspects of "people first" principle which are rely on the people, believe in the people, and develop the fundamental interests of the people as the starting point and foothold of the construction of major domestic policies. The sinicization of Marxist philosophy is the core of modern scientific development concepts. The interests of the people are always regarded as the working standards of the party and the state in addition to the public's partaking in the results of the national development and reform. The latest theory of Marxist philosophy is to be close to the public, benefit the public, and realize China's dream which leads to a more scientific socialism. In view of the real reality, socialism with Chinese characteristics is based on the interests of the mass society which is in line with the development of Marxist philosophy. If Marxist philosophy is separated from the mass society, it will lose its vitality and would turn into idealism and dogmatism. Hence, it is necessary to establish corresponding systems to avoid losing its basis and becoming just a tool to oppress people.

The theory should have profound understanding of the mass society to be supported by the masses. The popularization of Marxist philosophy in China should be linked to the interests of the people and consolidated with domestic conditions and economic development. In view of the reform, opening-up, as well as the construction of modern economy, the party and the government should strive to achieve reform and development to lead hundreds of millions of people to a well-off society. At present, China's reform and opening-up is moving toward deep-waters and the society is in the transition stage as there are high incidence of social contradictions. In this particular historical event, the development of Marxist philosophy in China should confront the relationship between personal interests and collectivism, as well as the relationship between local interests and overall interests. Moreover, in the era of global post-industrial development, China is facing complex domestic and international situations. Marx's philosophy shoulders the important task in the criticism of the capitalist ideology in which the use of ideology is a favorable tool to support epistemology and political theories.

\section{Conclusion}

Linking Marxist philosophy to the life of the mass society, this philosophy is used to guide the development and construction of social life, economy, and enterprises' operations. Marxist philosophy is a favorable weapon to open up social and public utilities which involve the compilation of books and the use of "popular" language. In this way, it would become a popular read. A large number of topics that are worth discussing are expounded in Marxist philosophical books. These philosophical theories are organically combined with 
the reality of life in order to promote greater practical significance.

\section{Disclosure statement}

The author declares no conflict of interest.

\section{References}

[1] Li P, 2019, Analysis of the basic principles of the popularization of Chinese Marxist philosophy. New Silk Road, ,000(011): 1.

[2] Hao L, 2019, The development process and method path of contemporary Chinese Marxist philosophy innovation. Marxist Philosophy, 000(004): 133-42. 